\title{
Effect of Yoga and Gender on Self-esteem and Aggression
}

\author{
Dr. Rajesh Baburao Shirsath ${ }^{1}$
}

\section{ABSTRACT:}

The present study to investigate the status of self-esteem and aggression among yoga performer and not performing students. The sample consists of 160 students of male and female students. With age ranging from 15 years to 25 years located at Jalna city. Two-way ANOVA was used for dependent variables of the total sample under study. A $2 \times 2$ factorial design will be used to analyzing the data. The Self-esteem Inventory developed by Dr. A.K. Srivastava and Aggression Questionnaires developed and standardized by Dr. G.C. The yoga performer students was found high level of self-esteem than yoga not performing students and the level of aggression was also high found in yoga not performing students than the yoga performer students. Yoga and gender also significant effect on aggression.

Keywords: Yoga, self-esteem and aggression.

The Sanskrit word "yoga" comes from the root "yuj" and has been translated as "to bind, join, attach and yoke, to direct and concentrate one's attention on, to use and apply" (Iyengar, 1966, p. 19), "joining" (Sivananda Yoga Centre, 1983 p. 15), "yoke," "unity," "discipline," or "effort" (Payne \& Usatine, 2002, p.5). The most common understanding of the word yoga is "union" and at its core, the purpose of yoga, is to cultivate a sense of unity - both a "union of the mind with the divine intelligence of the universe" (Raub, p.797) and a sense of union within the individual. Yoga enables a holistic healing of the individual. The philosophy perceives the mind and body as an integrated unity, for which it is considered a mind-body science. Historically, yoga teachers focused on theory rather than physical practice. Although seven of the Bhagavad-Gita's eighteen chapters include "yoga" in the title, and the majority of the chapters discuss yoga in verse, the Bhagavad-Gita includes no mention of yoga as asana (physical postures; see the translation by Prabhavananda \& Isherwood, 1944). It was in Pantanjali's work that the first mention of asana (physical yoga) was made. As outlined by Pantanjali, yoga included eight limbs, or disciplines, including yamas (ethical disciplines), niyamas (individual observances), asana (postures), pranayama (breath control), pratyahara (withdrawal of senses), dharana (concentration) dhyana (meditation), and samadhi (selfrealization or enlightenment).

\footnotetext{
${ }^{1}$ Assist. Professor, Department of psychology, Kala Mahavidyalaya Nadur(Ghat) Tq.kaij, Beed (M.S.)

(C) 2015 I R Shirsath; licensee IJIP. This is an Open Access Research distributed under the terms of the Creative Commons Attribution License (http://creativecommons.org/licenses/by/2.0), which permits unrestricted use, distribution, and reproduction in any Medium, provided the original work is properly cited.
} 
However, while yoga begins with physical practice, it is important that the yoga practitioner not stop with physical yoga. "Asanas are not the goal. They are a vehicle to access a deeper internal awareness" (Swenson, p. 7). The ultimate purpose of the physical yoga is to take the individual into the philosophy of yoga. The essence of yoga is the development of awareness and selfcontrol. A yoga practice ultimately teaches, through control of the body, that we have control of the mind. "As we improve our abilities of controlling the senses from wandering during practice, the subtle quality of concentration deepens. ... In time, the practice moves further internally and refinement of concentration develops as our ability to remain present is enhanced" (Swenson, 1999, p.6). This development of self-control enables the individual to be freed from the pain and suffering inherent in life. "When the senses are stilled, when the mind is at rest, when the intellect wavers not - then, say the wise, is reached the highest stage. This steady control of the sense and mind has been defined as Yoga. He who attains it is free from delusion" The individual learns to evaluate himself, rather than judge others, and to focus on self-growth, rather than attempts to change others.

While yoga has its roots in the Hindu religion, and while much of core yoga theory speaks to issues generally associated with religion (i.e., inner peace, understanding, awareness, union with self, union with a higher power), yoga is not a religion. "Nor even a philosophy - it is an extremely practical methodology for systematically expanding the conscious mind. ... Yoga is the science for overcoming the self-destructive and limiting beliefs and internal programs that keep individual life bound to the experiences of the Waking State of Consciousness" (MSI, 1995, p. 2). Payne and Usatine (2002). It is perhaps most accurate to say that yoga originated within the Hindu religion, became a philosophy and system all of its own, and now is a practice which is adaptable to the needs of the practitioner - yoga may be a religion, a philosophy, a science, a way of life, or simply a form of exercise.

\section{AGGRESSION:}

Aggression is a substitution behavioral activity that man does to inflict harm on others either by verbal mocking or by physical pain. Aggression is a behavior acquired by learning. A child learns to respond to different attitudes either by being aggressive or adaptive. Scientists believe that behavior is acquired according to the nature of the influencing factors of the environment a child lives in. If an environment is void of quarrelling, anger, hot-temper, and aggression, a child develops peaceful habits and conservative behavior. Besides, parents' way in dealing with their children has a great impact on acquiring an aggressive behavior or avoiding it. By encouraging their children to prove themselves without hurting others, parents help their children to maintain themselves and their rights.

Psychoanalysts believe that a child's agitation is usually accompanied by a conflict between feelings of love and hate to the other person who represents his mother. If the mother satisfies her demands, he will feel that she is a good person, but if she is late in fulfilling his need, threatens him, or shouts at him, she will become a bad figure to him. Child's aggression is, 
therefore, associated with his relationship with his mother. Frustration and troubles within this relationship arouses his anger and aggressiveness. Thus aggressive behavior is a phenomenon that appears in the child's early stages. He starts kicking and flicking objects, and sometimes he beats, curses, threatens or despises others. An aggressive child in naughty and indifferent to what will happen to him and agitated; he is uncooperative, easily affected and agitated, and noisy.

Gender: the outcome of researches, made in this respect, has proved that male aggressiveness is more direct, visible, and physical than female aggressiveness. This does not mean that males are more aggressive than females, but females show aggressiveness indirectly, invisibly, and most of the times, verbally, the different expectation of civilizations and the social practices of males and females might bring forth such differences.

Another reason for aggression is frustration. If a child's desires are not fulfilled and his needs are not satisfied, he becomes aggressive. Feeling deficient because of a physical defect, a repeated failure, or being of poor achievement in school, a child turns to be aggressive as a substitute to prove himself and thus to attain, a social rank. Jealousy in considered as one of the most important reasons, which pushes a child to take revenge of his brothers, friends or those who deprived him of his rights.

Educators affirm the necessity of differentiating between courage, and aggression, and some parents are wrong in believing that a child needs to be strong, courageous, and able to control others while proving himself no matter how he acts and what he does; such parents are to blame because they reinforce this attitude in their children. Scientists warn that parents should not be tolerant with the child's aggressiveness against others. They emphasize the importance of applying the principles of reward and punishment in order to make him feel that such a behavior in wrong, rejected, and unfavorable, and thus guiding him to behave properly and get rid of violence.

Family troubles that involve beating and quarrelling, reinforce, the child's aggressive behavior, especially if parents do not show any concern to upright their children's aggressive behavior, showing them its disadvantage.

\section{OBJECTIVE OF THE STUDY}

1. To investigate the effect of yoga on self-esteem among male and female students.

2. To investigate the effect of yoga on aggression among male and female students.

3. To find out the gender wise difference of self-esteem and aggression.

\section{HYPOTHESIS}

1. There will be significant difference of self-esteem between yoga performer and not performer students. 
2. There will be significant difference of aggression between yoga performer and not performer students.

3. There will be significant difference of self-esteem between male and female students.

4. There will be significant difference of self-esteem between male and female students.

\section{Sample:-}

The sample consist of 160 subject 80 yoga performer students ( 50 male and 50 female), 80 not perform yoga students ( 50 male and 50 female). The sample of the present study is shown as below. The subject selected in the sample in the age group of 10 to 20 who are living in urban areas.

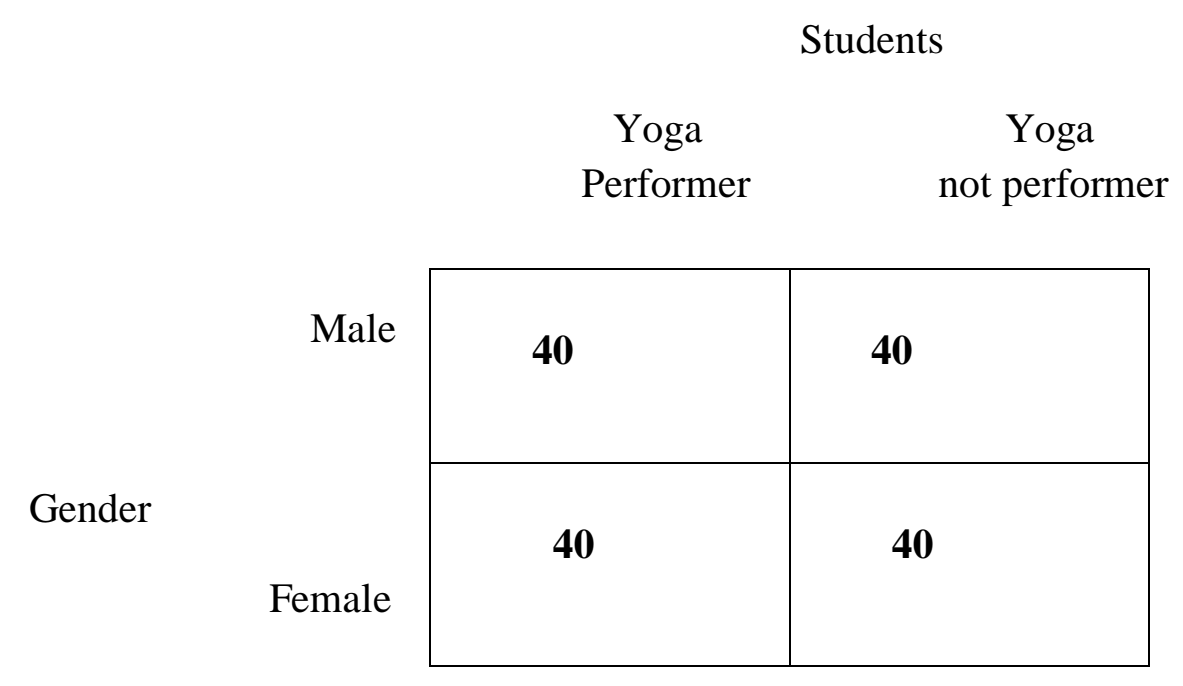

- Design:-

$2 \times 2$ factorial design will be used for research.

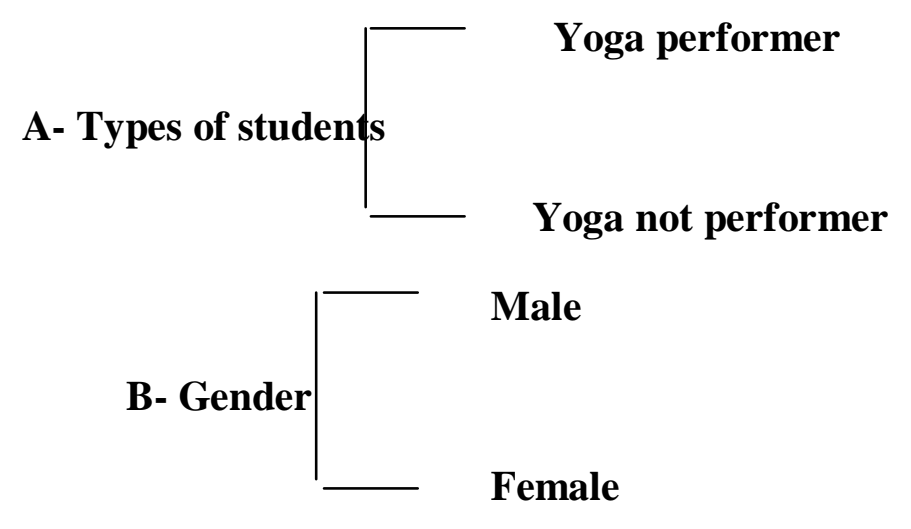




\section{Tools:}

Self-esteem Inventory:

The Hindi version of the Self-esteem inventory is constructed and standardized by M. S. Prasad and G. P. Thakur by the investigator was used for the study. It consists of 30 items presented in a 7 points rating format. The reliability of the inventory was estimated through test -retest and split half reliability method. Index of reliability co-efficient consequently 0.69 and 0.82 . The content validity of the mental health check list adequately assured as only those symptoms which showed 100 percent agreement amongst the judges regarding their relevance to the study of mental health were selected

\section{Aggression Questionnaire}

This questionnaire developed by Dr. G.C.Pati. In this questionnaire consist of 16 questions. Reliability coefficient of the aggression questioner was calculated by split-half method. Reliability coefficient .71 was found. The Pearson method $\mathrm{r} .82$ was found. The validity coefficient is significant above one percent level.

\section{RESULTS AND DISCUSSION}

Table No. 1.1 Summary of ANOVA Dependable variable Self-esteem

\begin{tabular}{|c|c|c|c|c|}
\hline Source & SS & Df & M S & F \\
\hline Yoga & 4928.40 & 1 & 4928.40 & 17.48 \\
\hline Gender & 2175.63 & 1 & 2175.63 & 7.72 \\
\hline $\begin{array}{c}\text { Students * } \\
\text { Gender }\end{array}$ & 4472.23 & 1 & 4472.23 & 15.86 \\
\hline Error & 43989.85 & 156 & 281.98 & \\
\hline Total & $\mathbf{5 1 0 5 3 6 . 0 0}$ & 160 & & \\
\hline
\end{tabular}

Table no. 1.1 shows the result for the Self-esteem as measured by self-esteem Inventory. Type of students is represented by main effect A. summary of two way ANOVA shows that main effect ' $\mathrm{A}$ ' is highly significant $(\mathrm{F}=17.48, \mathrm{df}=1$ and $156, \mathrm{P}<0.01)$. The result indicates that yoga performer and yoga not performer students thus, differ from each other significantly on the Selfesteem. According to summary of ANOVA, the hypothesis no.1 "There will be significant difference of self-esteem between yoga performer and not performer students." has been accepted.

The second factor was related to the gender. It is represented by main effect ' $\mathrm{B}$ '. Main effect ' $\mathrm{B}$ ' is also significant $(\mathrm{F}=7.72$, $\mathrm{df}=1$ and $156, \mathrm{P}<0.05)$. These $\mathrm{F}$ ratios indicate that there is significant difference between male and female of both yoga performer and not performer on self-esteem.

Result of ANOVA showed that main effect ' $A$ ' and main effect ' $B$ ' function independently. Interaction $\mathrm{A} \times \mathrm{B}$ is not significant $(\mathrm{F}=15.86$, df 1 and $156, \mathrm{P}>0.05)$. 
Table 1.2 Summary of ANOVA Dependable variable Aggression

\begin{tabular}{|l|l|l|l|l|}
\hline Source & \multicolumn{1}{|c|}{ Ss } & Df & Ms & F \\
\hline Yoga (A) & 189.23 & 1 & 189.23 & $52.57 * *$ \\
\hline Gender (B) & 3.03 & 1 & 3.03 & .84 \\
\hline AXB & 81.23 & 1 & 81.23 & 22.56 \\
\hline Error & 561.50 & 156 & 3.60 & \\
\hline Total & 7884 & 160 & & \\
\hline
\end{tabular}

*Significant 0.05 Level. ** Significant 0.01 Level.

In the above table shows that main effect of yoga $F$ value $(1,156)$ is 652.57 which is significant on 0.01 Level. The result indicates that yoga performer and yoga not performer students thus, differ from each other significantly on level of aggression.

Another main effect of gender $\mathrm{F}$ value $(1,156)$ is 3.03 which is not significant on 0.05 and 0.01 Level. The $\mathrm{F}$ value denotes the Female students differs not significant than Male students about aggression. And the interaction effect between yoga and gender F value $(1,156)$ is 22.56 which is significant both the level. These $\mathrm{F}$ ratios indicate that there is significant interaction effect between yoga and gender on aggression.

\section{REFERENCE:}

Anastasi, A., (1997) “Psychological Testing” New Delhi: Person education (Singapore) Pvt. Ltd. Indian Branch.

Cummings, LL (Eds), Research in organization behavior, volume 10, Greenwich CT: JAI Press. By Archer, John. Sep 2000,Sex differences in aggression between heterosexual partners: A metaanalytic review.Psychological Bulletin, Vol 126(5), 651-680.

Buck, R. (1985) “Cited in Emotional Quotient: The Emerging HR Planning Benchmark.” Indian Management, 76-80.

Crick NR, Grotpeter JK 1995 Relational aggression, gender and social psychological adjustment. Child dev.; 66(3): 710-22.

Edwards, A.L. (1971) "Statistical Analysis in Psychology and Education", New Delhi.

Freeman, F. S. (1966) "Theory and Practice of Psychological Testing", New Delhi.

Gilford, T. M., King, R.A., King, J. A. (1993) "Introduction to Psychology", Delhi: Tata McGraw Hill Publishing Company Limited.

Garrett, H.E. (1981), "Statistics in Psychology and Education", Bombay: Vakils, Fifer and Simon.

Johnson Robert J. \& Kaplan Howard B. 1988, "Gender, aggression and mental health intervention during early adolescence." Health \& Social behavior, Vol. 29(1),pp,53-64. 